\title{
Obituary
}

\section{Anna-Leena Siikala (1943-2016)}

The distinguished Finnish Professor Emerita of Folklore at the University of Helsinki, Anna-Leena Siikala, passed away on 27th February 2016 at the age of 73. Arja Anna-Leena Siikala (born Aarnisalo, formerly Kuusi) was an eminent scholar, teacher, and policymaker in the study of culture, language, folklore, and religion in Finland. She was Professor of Folkloristics at the University of Eastern Finland (Joensuu) between 1988 and 1994, and at Helsinki from 1995. She also worked as Acting Professor of Folklore and Comparative Religion at the University of Turku between 1979 and 1982. For her outstanding achievements she was appointed Academy Professor between 1999 and 2004, and awarded the title of Academician by the President of Finland, Tarja Halonen, in 2009. The mark of her fifty years' work in academia can best be seen not only in her outstanding scholarly books and publications but also in the contributions of her colleagues, disciples, and students and in their dedication to share and continue her intellectual heritage. In serving the scholarly community through her positions in national and international academic institutions, Professor Siikala was a formative figure in the organisation of graduate schools for doctoral training in the anthropological and ethnological sciences. She was President of the Finnish Anthropological Society between 1985 and 1991, Vice-President of the Finnish Society for the Study of Comparative Religion between 1982 and 1994, and President of the Finnish Literature Society between 1996 and 2002. She was the editor of Folklore Fellows Communications, which is published by the Finnish Academy of Sciences and Letters, between 2002 and 2009.

Siikala was one of the world's leading scholars of shamanism, narrative traditions, and mythic landscapes among the indigenous peoples of Northern Eurasia. From the 1960s her career charted the course opened by Professors Martti Haavio and Lauri Honko. She adopted an approach to research in which conceptual frameworks developed in the fields of folklore, comparative religion, and social and cultural anthropology, as well as the study of mentalities, merged. Her doctoral dissertation, The Rite Technique of the Siberian Shaman (1978), reflects some of the peculiarities of the Finnish school of folklore and mythology initiated by the 
founding fathers of folklore studies and comparative religion in Finland, Kaarle Krohn and Uno (Holmberg-)Harva. Siikala's scope was significantly broader than her predecessors', using ethnographic accounts of shamanic séances and journeys into insights from neurophysiology, psychology, and theories of altered states of consciousness in her attempt to explain psychic mechanism in the formation of the shaman's technique of ecstasy. She departed deliberately from the Eliadean phenomenology of religion, as well as from functionalistic explanations, to lay a firm foundation for an empirically tractable and more accurate ethnographic analysis of shamanic behaviour in its own cultural setting. By paying special attention to shamans' communicative roles, Siikala developed the Nordic tradition of role theory research first proposed by Hjalmar Sundén and Lauri Honko.

Siikala always emphasised the importance of striking a balance between empirical data and theoretical reflection. In her approach to issues of vernacular religious beliefs and practices she highlighted the significance of ethnographic fieldwork in obtaining reliable first-hand data. But she also criticised disciplinary practices based too one-sidedly on a grassroots level of understanding of conventional cultural phenomena. The present author came to an understanding of her points in person. I had several discussions with Siikala from the early stage of my academic career until she became my 'Doktormutter'. After one of many discussions at the beginning of the 1980s I received a letter from her, the purpose of which was to assist me in finding a path of wisdom through the thicket of the academic forest. In this letter, written on 15th November 1983, she gave me personal guidance on making a difference in academia. I had been anxious to find 'a field' to work on. She advised me to keep in mind that 'the major fault among fieldworkers is a certain kind of ethnographic vulgarity, a lack of theoretical sophistication in which too much value is placed on "the native's point of view"'. She stressed that an emerging young scholar needed to read up on and gain an understanding of scholarly traditions within their chosen field(s) and issues of theoretical importance. A historical orientation and a comparative approach to cultural materials was a methodological necessity. Later Siikala dealt with these issues in the scholarly context in the co-authored book Return to Culture (2005), written with her husband, the Finnish social anthropologist Jukka Siikala. The book is based on their fieldwork in the Southern Cook Islands in the 1980s and 1990s.

Field trips to Polynesia, and later - following the collapse of the Soviet Union in 1991 - to Russia to study Finno-Ugric ethnicities, led Siikala to an understanding of and focus on the primary role spatial memory plays 
in coding genre-specific information on landscape and local topography in mythic discourse. During the 1990s and in the first decade of the 21st century she was to carry out extensive field trips to the dwelling sites of the Udmurts, Komi, and Khanty in Russia. She worked with the Russian ethnographer Oleg Ulyashev to create a joint project on the mythology, folklore, and religion of the Khanty, Komi, and Udmurt. For example, in their book Hidden Rituals and Public Performances (2011) Siikala and Ulyashev depict how the Khanty mark and transform their ethnic domain by marking boundaries in everyday social space. They illustrated how everyday places in social life, and especially holy places in ritual sites, are used as signs to mark domestic space for the needs of divergent social worlds. Cultic places, cemeteries, deserted houses whose inhabitants have died, trees, or even the places where the ashes from houses are discarded and which must be avoided transform the landscape into a network of meaningful sites. The dynamic spiritual forces implied in this network affect how people use their everyday environment. Landscape is outlined by sacred sites and holy places. The spirits, the invisible inhabitants of certain areas and locations, are not only integral features of local topography, but the very source of territorial separation and ritual integration between the worlds of the supernatural and gendered mundane social space. Boundaries between the two worlds can be overcome and an inevitable interaction takes place. Topography acts as a necessary connector which defines value categories and social groups.

Siikala repatriated her in-depth research into ethnomythological worlds of minority populations in Oceania and Russia to Finland and its adjacent regions in two of her recent books, Mythic Images and Shamanism. A Perspective on Kalevala Poetry (2002) and the award-winning Itämerensuomalaisten mytologia (2012; available only in Finnish). Prehistoric religious traditions were one of the major focuses of Siikala's research interests. With her wide perspective on archaeological, linguistic, folkloric, and historical data she was able to offer a comprehensive view of the poetry of the Kalevala and the multifaceted cultural layers in which 'the ancient mythological worldview' lay dormant. Siikala was convinced - based on her extensive research that mythic discourses addressed both cultural and existential questions. Mythical narratives are elemental to social cognition in establishing a link to the immutable principal events of the past and acting as a register for notions of common origin. In this capacity myths have the power of selfdefinition. Research into mythical traditions is and has been, therefore, a vital element in the formation of ethnic and national identities. As such, 
mythic knowledge addresses not only the other world and its invisible agents, but the visible agents of this world that make and transform history and our notions of identity. With the passing of Anna-Leena Siikala, Finnish scholarship in the area of folklore, mythology, and religion has lost one of its greatest post-World War II mythographers.

Veikko Anttonen

Professor Emeritus of Comparative Religion

University of Turku 